\title{
Immunization coverage and factors associated with incomplete vaccination in children aged 12 to 59 months in health structures in Lomé
}

\author{
Wendpouiré I. C. Zida-Compaore ${ }^{1,2}$, Didier K. Ekouevi 1,2,3* ${ }^{*}$ Fifonsi A. Gbeasor-Komlanvi' ${ }^{2}$, Essèboè K. Sewu ${ }^{2}$, \\ Tetouyaba Blatome ${ }^{2}$, Adama D. Gbadoe ${ }^{4,5}$, Diparidè A. Agbèrè ${ }^{4,6}$ and Yawo Atakouma ${ }^{4,7}$
}

\begin{abstract}
Objective: To estimate the immunization coverage among children admitted for consultation or hospitalization in health structures of Lomé.

Results: A total of 797 respondent-child couples were included and $31.1 \%$ of them had their immunization cards. Complete immunization coverage was $69.3 \%$, 95\% confidence interval (65.9-72.5) and per antigen, it ranged from $83.1 \%$ for measles to $95.7 \%$ for BCG. Factors associated with incomplete immunization were the absence of immunization card ( $p<0.001)$, respondents' sex $(p<0.001)$, level of education $(p<0.001)$, marital status $(p<0.001)$ and the level of the health structure in the organization of the Togolese health system $(p<0.001)$. Obstacles to immunization were mainly the lack of money to pay for immunization fees (38.4\%) and forgetting the immunization appointment (28.1\%).
\end{abstract}

Keywords: Immunization coverage, Associated factors, Obstacles, Hospital studies, Togo

\section{Introduction}

Immunization is one of the most cost effective health interventions which helps prevent $2-3$ million deaths per year [1]. To protect children against vaccine preventable diseases and to facilitate their access to vaccines, the World Health Organization (WHO) and United Nations International Children's Emergency Fund (UNICEF) have implemented in 1977 the Expanded Program on Immunization (EPI) [2]. In Togo, the implementation of EPI is effective since 1980. Nowadays, it has become one of the country's public health priorities [3].

Monitoring of immunization program is usually carried out through vaccination coverage surveys. The first surveys conducted in Togo used the WHO cluster survey methodology [4] or household surveys such as the demographic and health surveys (DHS) or the Multiple

\footnotetext{
*Correspondence: didier.ekouevi@gmail.com

${ }^{1}$ Département de Santé Publique, Faculté des Sciences de la Santé, Université de Lomé, Lomé, Togo

Full list of author information is available at the end of the article
}

Indicator Cluster Survey (MICS). According to the third DHS conducted in 2013-2014 in Togo, 61\% of children aged 12-23 months were fully immunized based on immunization cards or mother's recall, and the immunization coverage was higher in urban $(66 \%)$ than in rural area (59\%) [5]. In 2010, immunization coverage was estimated at $63.8 \%$ among children aged less than 5 years in the fourth MICS [6].

Vaccination coverage surveys are often difficult to carry out because of their high financial cost, information bias when immunization cards are not available and households characteristics (geographic inaccessibility, climatic and security issues) [7]. Consequently, these surveys are not regularly conducted. However, it is important to monitor vaccination coverage indicators on a regular basis. Other sources of information on immunization coverage, such as hospital studies, must be explored to assess these indicators. Therefore, this study aimed to estimate vaccination coverage among children aged 
12-59 months seen in medical consultation or hospitalized in health structures in Lomé.

\section{Main text \\ Methods \\ Study design and population}

A cross-sectional study was carried out from April to August 2017 in five health structures in Lomé. Togo health system has a three-level pyramid structure: tertiary, secondary and primary levels. Therefore, we selected at least one health structure at each level of the health pyramid. The study was conducted in the two teaching hospitals (out of two) from tertiary level (Centres Hospitaliers Universitaires Sylvanus Olympio and Campus), two secondary-level health structures (out of two) (Centre Hospitalier Régional Lomé-Commune and Hôpital de Bè) and one randomly selected (out of 140) primary-level health structure (Centre Medico Social Adidogomé).

All children aged 12-59 months hospitalized or seen in consultation in selected health structures during the survey period were eligible for this study. At this age, children should have received all vaccines according to the EPI schedule in Togo. A systematic sampling method was used to select eligible participants. The health card of recruited children was marked with a sticker to avoid double counting.

With a vaccination coverage estimated at $61 \%$, a precision of $4 \%$ and a significance level of $5 \%$, the minimum sample size was estimated at 571 respondent-child couples.

\section{Data collection}

A 10-min pre-tested questionnaire was administered to children's respondent during a face-to-face interview. Information collected included data on child's health and immunization, the respondent's socio-demographic characteristics and knowledge on immunization, as well as the reasons for incomplete immunization. The availability of the immunization card was also assessed. If the card was not available, the vaccine injection sites were showed to the respondent for recall purpose.

\section{Definition of variables}

Complete immunization coverage was defined as the immunization status of a child who received all the doses of vaccines recommended by the Togo's EPI, including one dose of tuberculosis vaccine (BCG), four doses of oral poliomyelitis vaccine (OPV), three doses of pentavalent (PENTA) vaccine (conjugate vaccine against diphtheria, tetanus, pertussis, hepatitis viral B and infections to Haemophilus influenzae b), three doses of pneumococcus vaccine (PNEUMO), two doses of rotavirus vaccine
(ROTA), one dose of measles vaccine, one dose against rubella and one dose against yellow fever [8]. Otherwise, immunization status was defined as incomplete.

A knowledge score on immunization was constructed with five questions based on routine recommendations provided by midwives to parents after childbirth, including the total number of required immunization sessions, number of vaccines to be administered to children, ages at first and last vaccine, and citing at least two EPI vaccines. Each correct answer was worth one point and total score ranged from 0 (no correct answer) to 5 (correct answers to all five items).

\section{Statistical analysis}

Descriptive statistics were performed and results were presented with frequency tabulations and percentages. Quantitative variables were presented as medians with their interquartile range (IQR). Prevalence rates were estimated with their 95\% confidence interval (95\% CI). Logistic regression analyses were performed to identify factors associated with "incomplete immunization coverage”. All analyses were performed using $\mathrm{R}^{\circledR}$ software.

\section{Results}

A total of 797 were enrolled in the study, resulting in a response rate of $96.1 \%$ and $42.9 \%, 25.5 \%$ and $31.6 \%$ of study participants were recruited in primary, secondary and tertiary level health structures, respectively.

Respondents were mainly mothers (91.6\%), with median age of 30 years, (IQR: $26-34$ ) and $45.5 \%$ had a secondary school level education. Children's median age was 25 months (IQR: $17-36$ ) and $51.7 \%$ of recruited children were male (Table 1 ).

\section{Possession of immunization card}

Among recruited children, $31.1 \%$ came to the health care center with an immunization card. The proportion of children having an immunization card was $22.2 \%$, 39.9\% and $35.3 \%$ in primary, secondary and at tertiary level health structures, respectively $(\mathrm{p}<0.001)$. The reasons for the absence of the immunization card were: leaving the card at home $(91.9 \%)$, never having a card for the child (4.6\%) and the loss of the card (3.5\%).

\section{Immunization coverage}

Complete immunization coverage in our study was $69.3 \%$ (95\% CI 65.9-72.5). It was 70.0\% in primary level, $76.1 \%$ in the secondary level and $62.8 \%$ in tertiary level health structures $(\mathrm{p}=0.005)$.

Among the 541 children who did not have an immunization card, complete immunization coverage was $62.3 \%$ and was $84.6 \%$ among the 247 children who had immunization cards $(\mathrm{p}=0.002)$. 
Table 1 Sociodemographic characteristics of respondents and children according to the health structure level

\begin{tabular}{|c|c|c|c|c|c|c|c|c|}
\hline \multirow[t]{3}{*}{ Characteristics } & \multicolumn{6}{|c|}{ Health structures $(\mathrm{N}=797)$} & \multirow{2}{*}{\multicolumn{2}{|c|}{ Total }} \\
\hline & \multicolumn{2}{|c|}{ Primary level } & \multicolumn{2}{|c|}{ Secondary level } & \multicolumn{2}{|c|}{ Tertiary level } & & \\
\hline & $\mathbf{n}$ & $\%$ & $\mathbf{n}$ & $\%$ & $\mathrm{n}$ & $\%$ & $\mathrm{~N}$ & $\%$ \\
\hline \multicolumn{9}{|l|}{ Respondent } \\
\hline \multicolumn{9}{|l|}{ Sex } \\
\hline Female & 321 & 93.8 & 197 & 97.1 & 238 & 94.4 & 756 & 94.9 \\
\hline Male & 21 & 6.2 & 6 & 2.9 & 14 & 5.6 & 41 & 5.1 \\
\hline \multicolumn{9}{|c|}{ Relationship between respondent and child } \\
\hline Mother & 313 & 91.5 & 187 & 92.1 & 230 & 91.3 & 730 & 91.6 \\
\hline Father & 12 & 3.4 & 7 & 3.4 & 12 & 4.7 & 31 & 3.9 \\
\hline Grand parents & 5 & 1.5 & 5 & 2.5 & 7 & 2.8 & 17 & 2.1 \\
\hline Tutor & 2 & 0.6 & 1 & 0.5 & 0 & - & 3 & 0.4 \\
\hline Brother/sister & 3 & 0.9 & 0 & - & 0 & - & 3 & 0.4 \\
\hline Other & 7 & 2.1 & 3 & 1.5 & 3 & 1.2 & 13 & 1.6 \\
\hline \multicolumn{9}{|c|}{ Education level of respondent } \\
\hline No education & 43 & 12.6 & 32 & 15.8 & 28 & 11.1 & 103 & 12.9 \\
\hline Primary & 93 & 27.2 & 50 & 24.6 & 51 & 20.2 & 194 & 24.3 \\
\hline Secondary & 162 & 47.3 & 89 & 43.8 & 112 & 44.4 & 363 & 45.5 \\
\hline Higher & 42 & 12.3 & 32 & 15.8 & 61 & 24.3 & 135 & 17.0 \\
\hline MD & 2 & 0.6 & 0 & - & 0 & - & 2 & 0.3 \\
\hline \multicolumn{9}{|l|}{ Median age group } \\
\hline$<30$ years & 206 & 60.2 & 99 & 48.8 & 132 & 52.4 & 437 & 54.8 \\
\hline$\geq 30$ years & 128 & 37.5 & 103 & 50.7 & 120 & 47.6 & 351 & 44.1 \\
\hline MD & 8 & 2.3 & 1 & 0.5 & 0 & - & 9 & 1.1 \\
\hline \multicolumn{9}{|l|}{ Marital status } \\
\hline Never in union & 48 & 14.0 & 21 & 10.4 & 14 & 5.6 & 83 & 10.4 \\
\hline Married & 262 & 76.6 & 182 & 89.6 & 230 & 91.3 & 674 & 84.5 \\
\hline Other & 32 & 9.4 & 0 & - & 8 & 3.1 & 40 & 5.1 \\
\hline \multicolumn{9}{|l|}{ Occupation } \\
\hline Not working & 6 & 1.7 & 7 & 3.4 & 18 & 7.1 & 31 & 3.9 \\
\hline Salaried employee & 21 & 6.1 & 13 & 6.4 & 45 & 17.9 & 79 & 9.9 \\
\hline Housewife & 53 & 15.5 & 27 & 13.3 & 65 & 25.8 & 145 & 18.2 \\
\hline Retailer (self employed) & 122 & 35.7 & 79 & 39.0 & 47 & 18.6 & 248 & 31.1 \\
\hline Other & 140 & 41.0 & 77 & 37.9 & 77 & 30.6 & 294 & 36.9 \\
\hline \multicolumn{9}{|l|}{ Child } \\
\hline \multicolumn{9}{|l|}{ Sex } \\
\hline Male & 157 & 45.9 & 115 & 56.6 & 140 & 55.6 & 412 & 51.7 \\
\hline Female & 185 & 54.1 & 88 & 43.4 & 112 & 44.4 & 385 & 48.3 \\
\hline \multicolumn{9}{|l|}{ Age group (months) } \\
\hline $12-24$ & 149 & 43.6 & 120 & 59.1 & 129 & 51.2 & 398 & 49.9 \\
\hline $24-36$ & 98 & 28.6 & 46 & 22.7 & 70 & 27.8 & 214 & 26.9 \\
\hline $36-59$ & 95 & 27.8 & 37 & 18.2 & 53 & 21.0 & 185 & 23.2 \\
\hline \multicolumn{9}{|l|}{ Place of birth } \\
\hline Public structure & 266 & 77.8 & 161 & 79.3 & 205 & 81.3 & 632 & 79.3 \\
\hline Private structure & 71 & 20.8 & 37 & 18.2 & 46 & 18.3 & 154 & 19.3 \\
\hline Home & 1 & 0.3 & 3 & 1.5 & 0 & - & 4 & 0.5 \\
\hline Other & 4 & 1.1 & 2 & 1.0 & 1 & 0.4 & 7 & 0.9 \\
\hline
\end{tabular}


For all children, this coverage was $95.7 \%, 94.7 \%$ and 87.6\% for BCG, the first dose (OPV-0) and the fourth dose of poliovirus vaccine (OPV-3), respectively. For pentavalent vaccine, the coverage ranged from $94.2 \%$ for PENTA 1 to $87.8 \%$ for PENTA 3 while it was $83.1 \%$ for measles and $71.9 \%$ for yellow fever (Table 2).

\section{Knowledge on immunization}

Nearly $62.9 \%$ of respondents were unaware of the number of required immunization sessions and $96.0 \%$ did not know the number of vaccines children must receive. Almost three-quarters (73.2\%) of respondents had cited two Togo EPI vaccines. Ages at first and last vaccine were given by $4.7 \%$ and $20.3 \%$ of respondents, respectively. Knowledge scores on immunization varied from 0 (7.9\%) to $3(8.9 \%)$ and a score of 1 and 2 was reported for $45.0 \%$ and $38.2 \%$ of respondents respectively. Respondent's knowledge on immunization was higher in primary level health structures $(75.0 \%$ with a score of $3 / 5)$ compared with that of respondents of tertiary level health structures $(25.0 \%$ with a score of $3 / 5)(p=0.076)$.

\section{Barriers to immunization}

Among respondents of children with incomplete immunization $(n=242), 38.4 \%$ did not have money to pay for immunization fees; $28.1 \%$ reported that they forgot the immunization appointment and $8.7 \%$ did not have time to take their children to a health care center for vaccination.

The long waiting time at the health structure (5.4\%), the lack of vaccines $(4.1 \%)$ and the long distance from home to the health structure $(2.1 \%)$ were cited as the main contextual factors. Cultural beliefs or prohibitions were mentioned by $11.6 \%$ of respondents of children who were partially immunized.

\section{Factors associated with incomplete immunization}

After adjustment on the other variables, being a male respondent (aOR: $2.7 ; 1.3-5.7 ; \mathrm{p}<0.001)$, being not married (aOR: $2.6 ; 1.6-3.9 ; \mathrm{p}<0.001$ ), having primary education level (aOR: $2.2 ; 1.6-3.2 ; \mathrm{p}<0.001$ ), not having an immunization card (aOR: $3.5 ; 2.4-5.4 ; \mathrm{p}<0.001)$ and attending primary level health structure (aOR: 2.0 ; $1.3-$ $3.2 ; \mathrm{p}<0.001)$ were associated with incomplete immunization (Table 3 ).

\section{Discussion}

Overall, complete immunization coverage observed in the present study is similar to that reported in household surveys in 2013 and 2017 in Lomé with 62.2\% and 72.3\% respectively $[6,9]$. Although comparisons of immunization coverages must be done with caution because of difference in studies' methods (including the availability of immunization cards and the age range of study population), it should be noted that carrying out hospital-based study in Togo could be an opportunity to obtain immunization indicators at no additional cost. Indeed, in Togo, data on maternal and infant deaths are compiled weekly and immunization data can be collected as part of this existing surveillance system.

The immunization card is a paper used to record and track immunization coverage. In Togo, for household

Table 2 Immunization coverage of children by antigen

\begin{tabular}{|c|c|c|c|c|c|c|c|c|c|c|c|c|}
\hline & \multicolumn{9}{|c|}{ Health structures $(\mathrm{N}=797)$} & \multirow{2}{*}{\multicolumn{3}{|c|}{ Total }} \\
\hline & \multicolumn{3}{|c|}{ Primary level } & \multicolumn{3}{|c|}{ Secondary level } & \multicolumn{3}{|c|}{ Tertiary level } & & & \\
\hline & $\mathbf{N}$ & $\mathbf{n}$ & $\%$ & $\mathbf{N}$ & $\mathbf{n}$ & $\%$ & $\mathbf{N}$ & n & $\%$ & $\mathbf{N}$ & $\mathbf{n}$ & $\%$ \\
\hline All children & 342 & & & 203 & & & 252 & & & 797 & & \\
\hline$B C G$ & & 330 & 96.5 & & 190 & 93.6 & & 243 & 96.4 & & 763 & 95.7 \\
\hline PENTA 1/PNEUMO 1 & & 329 & 96.2 & & 190 & 93.6 & & 213 & 84.5 & & 751 & 94.2 \\
\hline PENTA 2/PNEUMO 2 & & 326 & 95.3 & & 188 & 92.6 & & 222 & 88.1 & & 736 & 92.4 \\
\hline PENTA 3/PNEUMO 3 & & 306 & 89.5 & & 178 & 87.7 & & 216 & 85.7 & & 700 & 87.8 \\
\hline OPV-0 & & 328 & 95.9 & & 185 & 91.1 & & 242 & 96.0 & & 755 & 94.7 \\
\hline OPV-1 & & 327 & 95.6 & & 186 & 91.6 & & 231 & 91.7 & & 744 & 93.4 \\
\hline OPV-2 & & 325 & 95.0 & & 184 & 90.6 & & 222 & 88.1 & & 731 & 91.7 \\
\hline OPV-3 & & 307 & 89.8 & & 177 & 87.2 & & 214 & 84.9 & & 698 & 87.6 \\
\hline ROTA-1 & & 289 & 84.5 & & 171 & 84.2 & & 197 & 78.2 & & 657 & 82.4 \\
\hline ROTA-2 & & 291 & 85.1 & & 166 & 81.8 & & 198 & 78.6 & & 655 & 82.2 \\
\hline Measles/rubella & & 245 & 71.6 & & 156 & 76.8 & & 178 & 70.6 & & 579 & 83.1 \\
\hline Yellow fever & & 241 & 70.5 & & 159 & 78.3 & & 173 & 68.6 & & 573 & 71.9 \\
\hline
\end{tabular}

BCG: Bacillus Calmette-Guerin; Penta: pentavalent vaccine (vaccine against diphtheria, Tetanus, pertussis, hepatitis B and Haemophilus influenzae); OPV: oral polio vaccine; Pneumo: Pneumococcus conjugated vaccine; Rota: rotavirus vaccine 
Table 3 Factors associated with incomplete immunization coverage

\begin{tabular}{|c|c|c|c|c|c|c|c|c|c|c|}
\hline \multirow[t]{2}{*}{ Characteristics of respondents $(\mathrm{N})$} & \multicolumn{2}{|c|}{$\begin{array}{l}\text { Children fully } \\
\text { immunized }\end{array}$} & \multicolumn{2}{|c|}{$\begin{array}{l}\text { Children partially } \\
\text { or no immunized }\end{array}$} & \multicolumn{3}{|c|}{ Univariate analysis } & \multicolumn{3}{|c|}{ Multivariate analysis } \\
\hline & $\mathbf{N}$ & $\%$ & $\mathbf{N}$ & $\%$ & OR & $95 \% \mathrm{Cl}$ & p-value & $\mathrm{aOR}$ & $95 \% \mathrm{Cl}$ & p-value \\
\hline $\operatorname{Sex}(n=785)$ & & & & & & & 0.008 & & & $<0.001$ \\
\hline Female & 527 & 96.9 & 223 & 92.5 & 1 & & & 1 & & \\
\hline Male & 17 & 3.1 & 18 & 7.5 & 2.5 & {$[1.3 ; 4.9]$} & & 2.7 & {$[1.3 ; 5.8]$} & \\
\hline Relationship between respondent and child $(n=784)$ & & & & & & & 0.002 & & & \\
\hline Mother & 515 & 94.5 & 210 & 87.9 & 1 & & & & & \\
\hline Other & 30 & 5.5 & 29 & 12.1 & 2.4 & {$[1.4 ; 4.1]$} & & & & \\
\hline Education level $(n=787)$ & & & & & & & $<0.001$ & & & $<0.001$ \\
\hline$>$ Primary & 371 & 67.9 & 123 & 51.0 & 1 & & & 1 & & \\
\hline$\leq$ Primary & 175 & 32.1 & 118 & 49.0 & 2.0 & {$[1.5 ; 2.8]$} & & 2.2 & {$[1.6 ; 3.1]$} & \\
\hline Median age group $(n=780)$ (years) & & & & & & & 0.323 & & & \\
\hline$\geq 30$ & 247 & 45.7 & 100 & 41.8 & 1 & & & & & \\
\hline$<30$ & 294 & 54.3 & 139 & 58.2 & 1.2 & {$[0.9 ; 1.6]$} & & & & \\
\hline Marital status $(n=787)$ & & & & & & & $<0.001$ & & & $<0.001$ \\
\hline Married & 484 & 88.6 & 184 & 76.4 & 1 & & & 1 & & \\
\hline Other & 62 & 11.4 & 57 & 23.6 & 2.4 & {$[1.6 ; 3.6]$} & & 2.6 & {$[1.6 ; 4.0]$} & \\
\hline Religion $(n=786)$ & & & & & & & 0.0022 & & & \\
\hline Catholic & 232 & 42.6 & 75 & 31.1 & 1 & & & & & \\
\hline Protestant & 155 & 28.4 & 66 & 27.4 & 1.3 & {$[0.9 ; 1.9]$} & & & & \\
\hline Muslim & 72 & 13.2 & 52 & 21.6 & 2.2 & {$[1.4 ; 2.5]$} & & & & \\
\hline Other & 86 & 15.8 & 48 & 19.9 & 1.7 & {$[1.1 ; 2.7]$} & & & & \\
\hline Occupation $(n=785)$ & & & & & & & 0.002 & & & 0.053 \\
\hline Not working & 23 & 4.2 & 7 & 2.9 & 1 & & & 1 & & \\
\hline Salaried employee & 66 & 12.1 & 12 & 5.0 & 0.6 & {$[0.2 ; 1.8]$} & & 0.6 & {$[0.2 ; 1.9]$} & \\
\hline Housewife & 81 & 14.9 & 63 & 26.3 & 2.6 & {$[1.1 ; 6.8]$} & & 1.8 & {$[0.7 ; 5.1]$} & \\
\hline Retailer (self employed) & 174 & 31.9 & 71 & 29.6 & 1.3 & {$[0.6 ; 3.5]$} & & 1.1 & {$[0.4 ; 3.1]$} & \\
\hline Other & 201 & 36.9 & 87 & 36.2 & 1.4 & {$[0.6 ; 3.3]$} & & 1.2 & {$[0.5 ; 3.2]$} & \\
\hline House type $(n=786)$ & & & & & & & 0.3944 & & & \\
\hline Multiple dwelling unit & 323 & 59.3 & 135 & 56.0 & 1 & & & & & \\
\hline Single family home & 222 & 40.7 & 106 & 44.0 & 1.1 & {$[0.8 ; 1.6]$} & & & & \\
\hline Health structures $(n=788)$ & & & & & & & 0.008 & & & $<0.001$ \\
\hline Secondary level & 153 & 28.0 & 48 & 19.8 & 1 & & & 1 & & \\
\hline Tertiary level & 157 & 28.8 & 93 & 38.5 & 1.4 & {$[0.9 ; 2.0]$} & & 1.0 & {$[0.7 ; 1.6]$} & \\
\hline Primary level & 236 & 43.2 & 101 & 41.7 & 1.9 & {$[1.2 ; 2.9]$} & & 2.0 & {$[1.3 ; 3.2]$} & \\
\hline Sex of the child $(n=786)$ & & & & & & & 0.3544 & & & \\
\hline Female & 266 & 48.8 & 109 & 45.2 & 1 & & & & & \\
\hline Male & 279 & 51.2 & 132 & 54.8 & 1.1 & {$[0.8 ; 1.6]$} & & & & \\
\hline Age of child ( $n=788$ ) (months) & & & & & & & 0.9514 & & & \\
\hline $12-24$ & 286 & 52.4 & 124 & 51.2 & 1 & & & & & \\
\hline $24-36$ & 136 & 24.9 & 61 & 25.2 & 1.0 & {$[0.7 ; 1.5]$} & & & & \\
\hline $36-59$ & 124 & 22.7 & 57 & 23.6 & 1.1 & {$[0.7 ; 1.5]$} & & & & \\
\hline Birth order $(n=764)$ & & & & & & & 0.031 & & & \\
\hline 1 & 213 & 40.0 & 70 & 30.1 & 1 & & & & & \\
\hline 2 & 162 & 30.5 & 80 & 34.5 & 1.5 & {$[1.0 ; 2.2]$} & & & & \\
\hline$\geq 3$ & 157 & 29.5 & 82 & 35.4 & 1.6 & {$[1.1 ; 2.3]$} & & & & \\
\hline Availability of immunization card $(n=779)$ & & & & & & & $<0.001$ & & & $<0.001$ \\
\hline Yes & 209 & 38.7 & 38 & 15.9 & 1 & & & 1 & & \\
\hline No & 331 & 61.3 & 201 & 84.1 & 3.3 & {$[2.3 ; 4.9]$} & & 3.5 & {$[2.4 ; 5.4]$} & \\
\hline Knowledge level $(n=89)$ & & & & & & & 0.197 & & & \\
\hline$\geq 2$ & 32 & 46.4 & 6 & 30.0 & 1 & & & & & \\
\hline$\leq 1$ & 37 & 53.6 & 14 & 70.0 & 2.0 & {$[0.7 ; 6.3]$} & & & & \\
\hline
\end{tabular}

aOR: adjusted odds-ratio; $\mathrm{Cl}$ : confidence interval 
surveys conducted in 2012 and in 2013, it was available for $77 \%$ and $70 \%$ of recruited children, respectively $[5,10]$. Difference in the availability of immunization card can be explained by the study setting and the study population. The proportion of children who came to the hospital with their immunization card was greater than that of $24 \%$ observed in a multicenter study conducted in Cameroon, Central African Republic and Senegal, among hospitalized children aged 3 months to 6 years between April 2009 and May 2010 [11]. In our study, nine respondents in ten who did not have the immunization card declared that the card was left at home while the children of household surveys were aged 12-23 months, with higher odds of immunization card retention [12].

Not having an immunization card was associated with incomplete immunization. Similar findings about immunization card have been reported in Senegal (aOR: 8.27; 95\% CI 4.18-16.50) and in Ghana (aOR: 50.30; 95\% CI 14.40-175.92) $[13,14]$. Using web based tracking system and/or mobile phone could be innovative ways to monitor the immunization coverage of children and reduce the risk of losing the card. However, studies should be carried out to assess these interventions' efficacy and sustainability. Currently, in Côte d'Ivoire, children can be registered in a database at the first visit for BCG to allow for catch up of vaccines, but this approach has not been yet evaluated. In their studies, Abdulraheem et al. and Wiysonge et al. $[15,16]$ reported that the lack of time, the poor education level of mother and the poor economic household were strongly associated with incomplete immunization. A study conducted in six West African countries found that being born at home, mothers lacking access to the media, family poverty and illiteracy of mothers were factors associated with incomplete immunization [17]. Health authorities should organize immunization campaigns to allow for catch-up of missed vaccines. Also, there is a need to strengthen sensitization on immunization since the knowledge score of respondents is low.

Barriers to incomplete immunization in our study were also reported by Ndiaye et al. [13] in Senegal, Makoutodé et al. [18] in Benin. In Cameroon and Togo, studies mentioned financial and geographic inaccessibility as main bottlenecks for complete immunization [11, 19]. Immunization costs have been reported in this study; the respondents declared that they have to pay a certain amount for consumables or immunization card during the EPI sessions which should be free.

This hospital survey was easier to carry out in terms of time and costs than household surveys. It must lead to change in routine practices of health providers such as the systematic verification of immunization cards at each consultation or hospitalization and the application of catch-up strategies for missed vaccines.

\section{Limitations}

Our study has some limits: PENTA and PNEUMO vaccines are administered during the same immunization session but in some immunization cards, only the date of immunization was reported; vaccines names and tags were not recorded. Therefore, we could not determine with precision which vaccine was administered, leading to an underestimation of antigen specific immunization coverage among children who had their immunization card. Moreover, the study was restricted to Lomé and the results cannot be extrapolated nationwide. In this survey, for the children who have not an immunization card, the immunization status was determined based on declarative data of respondents; this could be a source of memory and classification bias with an underestimation or overestimation of children's immunization status.

\section{Abbreviations}

95\% Cl: 95\% confidence interval; aOR: adjusted odds ratio; BCG: tuberculosis vaccine; EPI: Expanded Program on Immunization; IQI: interquartile interval; MD: missing data; MICS4: Fourth Multiple Indicator Cluster Survey; OPV: oral polio vaccine; PENTA: pentavalent vaccine; PNEUMO: pneumococcal vaccine; ROTA: vaccine against rotavirus gastroenteritis; UNICEF: United Nations International Children's Emergency Fund; WHO: World Health Organization.

\section{Authors' contributions}

DKE, WICZC and FAGK conceived the study and participated in its design and coordination. ADG, DAA, YA and TB participated in the study design and data collection. WICZC and EKS performed statistical analyses. DKE, WICZC and FAGK wrote the first draft of the manuscript and ADG, DAA, YA, EKS and TB subsequently revised the manuscript. All authors read and approved the final manuscript.

\section{Author details \\ ${ }^{1}$ Département de Santé Publique, Faculté des Sciences de la Santé, Université de Lomé, Lomé, Togo. ${ }^{2}$ Centre Africain de Recherche en Epidémiologie et en Santé Publique (CARESP), Lomé, Togo. ${ }^{3}$ ISPED, Université de Bordeaux \& Centre INSERM U1219-Bordeaux Population Health, Bordeaux, France. \\ ${ }^{4}$ Département de Pédiatrie, Faculté des Sciences de la Santé, Université de Lomé, Lomé, Togo. ${ }^{5}$ Hôpital de Bè, Lomé, Togo. ${ }^{6}$ Centre Hospitalier Régional de Lomé-Commune, Lomé, Togo. ${ }^{7}$ Centre Hospitalier Universitaire Sylvanus Olympio, Lomé, Togo.}

\section{Acknowledgements}

We are thankful to the children's parents who accepted to participate in this study and to the staff of the health structures where the study was conducted for their technical and logistical support.

\section{Competing interests}

The authors declare that they have no competing interests.

Availability of data and materials

All data used for the present study are available and could be requested from the authors.

\section{Consent for publication \\ Not applicable.}

\section{Ethics approval and consent to participate}

This study was approved by the National Ethics Committee of the Ministry of Health in Togo ( $n^{\circ} 06 / 2017 / C B R S$ ) and authorizations were obtained from the directors of each participating health structure. All respondents gave a written informed consent before enrollment in the study. 


\section{Funding}

This research receives no specific grant from any funding agency in the public, commercial or not-for-profit sectors.

\section{Publisher's Note}

Springer Nature remains neutral with regard to jurisdictional claims in published maps and institutional affiliations.

Received: 13 December 2018 Accepted: 6 February 2019

Published online: 14 February 2019

\section{References}

1. World Health Organization. Immunization. Geneva: WHO. http://www. who.int/topics/immunization/en/. Accessed 26 Nov 2018.

2. Santoni F. Le programme élargi de vaccination: 25 ans demain. Méd Trop. 2001;61(2):177-86.

3. Fitzgibbon B, Ackermann L, Murphy K, Deming M, Gindler J. Programme élargi de vaccination (PEV) dans 12 pays Africans 1982-1993. Atlanta: Stanley O FOSTER; 1994.

4. Santo EGDE, Floury B. Le programme élargi de vaccination dans les pays francophones d'Afrique de I'Ouest : tendances et perspectives. Cah Détudes Rech Francoph Santé. 1991;1(2):109-16.

5. République du Togo - Enquête Démographique et de Santé 2013-2014. http://microdata.worldbank.org/index.php/catalog/2241. Accessed 4 Mar 2017.

6. Landoh DE, Ouro-kavalah F, Yaya I, Kahn A-L, Wasswa P, Lacle A, et al. Predictors of incomplete immunization coverage among one to five years old children in Togo. BMC Public Health. 2016;13(16):968.

7. Cutts FT, Claquin P, Danovaro-Holliday MC, Rhoda DA. Monitoring vaccination coverage: defining the role of surveys. Vaccine. 2016;34(35):4103-9.

8. Saliou P. Le programme élargi de vaccination (PEV) : origine et évolution. Développement et Santé. https://devsante.org/articles/le-programmeelargi-de-vaccination-pev-origine-et-evolution. Accessed 21 Feb 2018.
9. Ekouevi DK, Gbeasor-Komlanvi FA, Yaya I, Zida-Compaore WI, Boko A, Sewu E, et al. Incomplete immunization among children aged 12-23 months in Togo: a multilevel analysis of individual and contextual factors. BMC Public Health. 2018;18(1):952.

10. Guedehoussou T, Djinadou MG, Atakouma NK, Tatagan-Agbi K, Assimadi JK. Causes de non vaccination et d'abandon vaccinal en zone urbaine à Lomé (Togo). J Rech Sci Univ Lomé. 2012;14(2):187-9.

11. Bekondi C, Zanchi R, Seck A, Garin B, Giles-Vernick T, Gody JC, et al. HBV immunization and vaccine coverage among hospitalized children in Cameroon, Central African Republic and Senegal: a cross-sectional study. BMC Infect Dis. 2015;15(1):267.

12. Sheikh SS, Ali SA. Predictors of vaccination card retention in children 12-59 months old in Karachi, Pakistan. Oman Med J. 2014;29(3):190-3.

13. Ndiaye NM, Ndiaye P, Diedhiou A, Gueye AS, Tal-Dia A. Facteurs d'abandon de la vaccination des enfants âgés de 10 à 23 mois à Ndoulo (Sénégal). Cah Détudes Rech Francoph Santé. 2009;19(1):9-13.

14. Baguune B, Ndago JA, Adokiya MN. Immunization dropout rate and data quality among children 12-23 months of age in Ghana. Arch Public Health. 2017;75:18.

15. Abdulraheem IS, Onajole AT, Jimoh AAG, Oladipo AR. Reasons for incomplete vaccination and factors for missed opportunities among rural Nigerian children. J Public Health Epidemiol. 2011;3(4):194-203.

16. Wiysonge CS, Uthman OA, Ndumbe PM, Hussey GD. Individual and contextual factors associated with low childhood immunisation coverage in sub-Saharan Africa: a multilevel analysis. PLoS ONE. 2012;7(5):e37905.

17. Douba A, Aka LBN, Yao GHA, Zengbe-Acray P, Akani BC, Konan NG. Sociodemographic factors associated with incomplete immunization or children aged 12 to 59 months in six West African countries. Sante Publique Vandoeuvre-Nancy Fr. 2015;27(5):723-32.

18. Makoutode M, Mohzmed S, Paraıso NM, Akpaka Nago MR, Bessaoud K. Influence de certaines caractéristiques parentales sur la couverture vaccinale des nourrissons au Bénin. Méd Trop. 2009;69(3):267-71.

19. Ba Pouth SFB, Kazambu D, Delissaint D, Kobela M. Immunization coverage and factors associated with drop-out in children 12 to 23 months in Djoungolo-Cameroon Health District in 2012. Pan Afr Med J. 2014;17:91.

Ready to submit your research? Choose BMC and benefit from

- fast, convenient online submission

- thorough peer review by experienced researchers in your field

- rapid publication on acceptance

- support for research data, including large and complex data types

- gold Open Access which fosters wider collaboration and increased citations

- maximum visibility for your research: over 100M website views per year

At BMC, research is always in progress.

Learn more biomedcentral.com/submissions 